Louisiana State University

LSU Digital Commons

Faculty Publications

Department of Geography \& Anthropology

1993

\title{
Long-distance staple transport in western Mesoamerica: Insights through quantitative modeling
}

Andrew Sluyter

Louisiana State University, asluyter@lsu.edu

Follow this and additional works at: http://digitalcommons.lsu.edu/geoanth_pubs

\section{Recommended Citation}

Sluyter, Andrew, "Long-distance staple transport in western Mesoamerica: Insights through quantitative modeling" (1993). Faculty Publications. 65.

http://digitalcommons.lsu.edu/geoanth_pubs/65

This Article is brought to you for free and open access by the Department of Geography \& Anthropology at LSU Digital Commons. It has been accepted for inclusion in Faculty Publications by an authorized administrator of LSU Digital Commons. For more information, please contact gcoste1@lsu.edu. 


\title{
LONG-DISTANCE STAPLE TRANSPORT IN WESTERN MESOAMERICA:
}

\section{Insights through quantitative modeling}

\author{
Andrew Sluyter \\ Department of Geography, The University of Texas at Austin, Austin, TX 78712-1098, USA
}

\begin{abstract}
Conceptualizations of pre-Hispanic staple transport remain underdeveloped. Conventional wisdom has long maintained that while "prestige goods" could demand long-distance transport, staple transport was short distance. A quantitative model reveals the fallacy of that argument and establishes the possibility of long-distance, overland staple transport in Mesoamerica by using maize tribute transport between Zempoala and Tenochtitlan as an example. This conclusion has implications for understanding Mesoamerican interregional exchange, ecology, and society.
\end{abstract}

Current conceptualizations of pre-Hispanic staple transport in western Mesoamerica remain underdeveloped. Despite the central role that interregional trade and tribute play in many models of ecological and social process, few scholars have systematically examined the logistics of transport (Drennan 1984a: 27-28). The Aztecs and their predecessors lacked suitable streams for water transport or suitable draft animals and therefore had to rely on overland cartage by human bearers. Consequently, conventional wisdom maintains that staple transport was "short distance"; only luxury items such as cacao and jadeite had the range to demand "long-distance" transport (Hassig 1981:178-179, 1985:24-28; Logan and Sanders 1976:46; Price 1978; Rees 1975:326). The theoretical context for this belief is economic location theory and the more general literature on society and trade, which emphasizes long-distance transport of "prestige goods" (Chapman 1957; Dalton 1975; Polanyi et al. 1957; Renfrew 1975; von Thünen 1966).

This view has influenced reconstructions of aboriginal ecologies and societies. For example, various researchers have attempted to estimate the population of a region based on its hectareage of relict agricultural fields or potentially arable lands (Denevan 1976:12, 1982:188-193; Denevan and Turner 1985; Sanders 1976a:131-135; Sanders et al. 1979:131-135). Measuring the hectarage of relict fields or arable lands, multiplying by yield per hectare, and dividing by consumption per person equals the maximum possible population. One of the central assumptions of this method is that "the food supply, at least the staples, were produced locally and that only small quantities were imported" (Sanders 1976b:137). In addition, considerations of the role of interregional exchange in social processes have also assumed a lack of long-distance staple transport, focusing instead on durable goods such as ceramics (Drennan 1984b; Smith 1990). Yet control of access to staples likely played a central role in state formation. Such control could equally have been through the organization of interregional exchange networks as through the organization of, for example, regional irrigation systems.

This paper only touches on such broad issues of ecological and social theory. Its central purpose is to question, from an energetics perspective, the validity of discounting, a priori, the possibility of long-distance staple transport. I first review the existing model of staple transport and discuss its shortcomings. Then I present a quantitative model and an example that illuminate the nature of maize transport in western Mesoamerica and establish the possibility of long-distance, overland staple transport.

\section{THE EXISTING MODEL}

The primary staple food throughout Mesoamerica was maize. Despite its importance, few researchers have attempted to model maize transport quantitatively and make the vaguely conceived terms "long distance" and "short distance" problematic (Drennan 1984b). Calculating the maximum range for a luxury item such as cacao or jadite is difficult because the range depends on cultural values and perceptions. The range of a staple food, however, is more fundamentally a matter of nutritional energy costs and benefits. A positivistic model that incorporates such concepts as "the principle of least effort" seems quite applicable (Jochim 1981:3-31; Zipf 1949:1-12). Ultimately, however, cultural considerations are always of concern, and economistic models can only provide insights into the material parameters of a specific context. Nonetheless, a theoretical break-even distance - "a range" - exists for every staple food at which the energy consumed by the bearer begins to exceed the energy contained in the load.

Sanders and Santley suggest $150 \mathrm{~km}$ as the "maximum distance for portage of basic foods as part of a tax obligation" (Sanders and Santley 1983:246). In a more detailed and explicit analysis, Drennan (1984b) postulates that energetically rational 
maize importers would never have expended more calories in importing maize than they gained from that maize. Therefore, assuming that a bearer carried a $30-\mathrm{kg}$ standard load containing $108,300 \mathrm{Cal}$, traveled $36 \mathrm{~km}$ per day, and expended 3,456 Cal per day, Drennan calculates an absolute maximum transport distance of $1,116 \mathrm{~km}$. At that distance the bearers would have consumed 107,136 Cal, or $99 \%$ of their loads (i.e., 107,136 $\mathrm{Cal} \div 3,456 \mathrm{Cal} /$ day $=31$ days, and 31 days $\times 36 \mathrm{~km} /$ day $=$ $1,116 \mathrm{~km})$. Since the bearers would have to make a round trip, Drennan "halves" this figure to $550 \mathrm{~km}$. And since "the net energy transfer must be significantly greater than zero" (Drennan 1984b:106), he further halves this figure to $275 \mathrm{~km}$, ensuring the importers a $100 \%$ energy profit for their investment. He does not justify such a large profit margin, but even this distance, he feels, is probably the extreme range for maize:

[A]ttempts to understand overland transport of food staples farther than $275 \mathrm{~km}$ or so in terms of contribution to the sustenance of a population ... seem to be completely misguided, and such transport should ordinarily involve a considerably shorter distance. (Drennan 1984b:107)

Other researchers have accepted Drennan's conclusion as a premise in their own research (e.g., Bell et al. 1988; Hirth 1991).

\section{SOME SHORTCOMINGS OF THE EXISTING MODEL}

Recent research in central Veracruz suggests that the Totonacs and Aztecs exceeded Drennan's proposed maximum distance for maize transport. In what Mesoamericanists had long considered to be a subhumid zone with little agricultural potential, the remains of intensive agriculture are now apparent. In these tropical lowlands, relict wetland fields, sloping-field terraces, and possibly canal irrigation indicate agricultural intensification and high levels of production (Doolittle 1990:113-115; Siemens 1989; Sluyter and Siemens 1992). Although the chronology of these agricultural systems is far from clear, they begin to confirm sixteenth-century reports that the lowland Totonacs produced a surplus of maize and at times exported it to the Basin of Mexico. In 1454, the Aztecs imported maize from the Totonacs to ameliorate a famine in the Basin of Mexico (Durán 1867: Chapter XXX; Torquemada 1969:Book II, Chapter XLVII; also see Hassig 1981). Another famine early in the sixteenth century had a similar result, but this time with the Totonacs under Aztec rule (Kelly and Palerm 1952:7).

The main transportation route from the Totonac capital of Zempoala to the Aztec capital of Tenochtitlan led up the eastern escarpment near Cofre de Perote, through the Basin of Puebla, and between the volcanoes Ixtaccihuatl and Popocatepetl into the Basin of Mexico (Figure 1) (West and Augelli 1966:251; but see Rees [1975] for an alternate route). This route kept south of the territory of the Tlaxcalans, with whom the Aztecs were at war from 1455 to 1521 (Davies 1973:228-229) and is approximately $396 \mathrm{~km}$ long, exceeding Drennan's $275-\mathrm{km}$ range by $44 \%$ and Sanders and Santley's $150-\mathrm{km}$ range by $164 \%$. This seeming anomaly stimulated the following reappraisal of Drennan's model and the construction of a new model.

Until now, internal criticism of Drennan's model has focused on the quantities he assumes for his elements rather than the

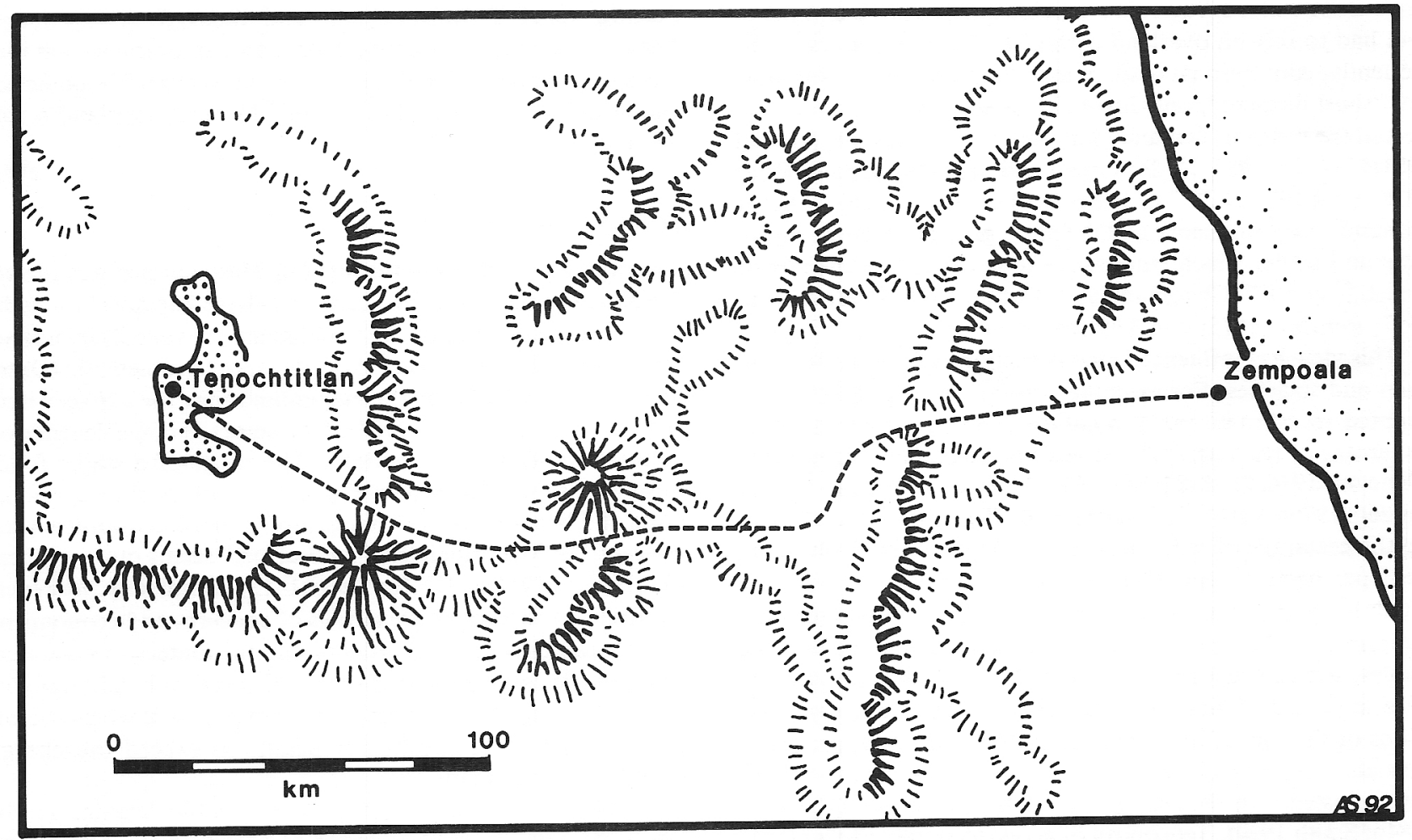

Figure 1. The 396-km-long transportation route from the Totonac capital of Zempoala to the Aztec capital of Tenochtitlan (base map after Blacker [1963:152]). 
relationships among those elements (see Zeitlin [1991] for an external critique of energetic modeling, including Drennan's, particularly its inherent ethnocentrism). Drennan's assumption of a $30-\mathrm{kg}$ standard load might well be too low given ethnohistorical and ethnographic accounts of loads up to $90 \mathrm{~kg}$ (Reyman and Dirks 1985; Sluyter 1990:78). His assumption of a 36-km daily travel distance might also be too low (Reyman and Dirks 1985:889). Nonetheless, such unresolvable discussion over quantities, which no doubt did vary spatially and temporally but are not recorded in standard units (Hassig 1986), does not seriously challenge Drennan's conclusion. For example, Phillips (1954:19, Figure 5) demonstrates that the ratio between additional weight carried and caloric expenditure is constant below $20 \mathrm{~kg}$; but beyond this point the relationship becomes exponential. Employing these data, Drennan demonstrates that a $90-\mathrm{kg}$ load carried $72 \mathrm{~km}$ per day results in a maximum transport distance of $341 \mathrm{~km}$ (Drennan 1985:892). This distance is only $24 \%$ greater than $275 \mathrm{~km}$ despite trebling the load and doubling the walking distance per day, figures that the ethnohistoric and ethnographic data indicate are absolute - and probably atypical maximums.

\section{A QUANTITATIVE MODEL FOR LONG-DISTANCE MAIZE TRANSPORT}

Rather than questioning the quantities Drennan employs, the model I propose suggests that the relationships between the elements of his model are ill-conceived. Allowing for energy inputs at locations intermediate to the exporter of the transported maize and its importer yields a theoretical maximum transport distance of infinity. Drennan's claim that "whether bearers carry their own food or forage along the way" results in "a net energy loss to the importers" is incorrect (Drennan 1984b:106). In reality, because of the energy cost of transport between the intermediate locations and the importer, part of any amount of energy those intermediate locations export is lost to the importer. The importer's most rational strategy is to use the intermediate locations' maize in situ. One way to achieve that end is to use the intermediate locations' maize to feed bearers transporting maize from a more distant exporter. Therefore, theoretically at least, the importer can achieve a net energy profit even when the maize comes from as far away as several thousand kilometers.

The following quantitative model formalizes this interpretation and provides a means for examining staple transport in specific cases. At the most basic level, the energy profit (EP) at any location $z\left(\mathrm{EP}_{z}\right)$, is equal to the energy acquired (EA) at any other location $y\left(\mathrm{EA}_{y}\right)$, minus the energy expended in transportation from $y$ to $z\left(\mathrm{ET}_{y z}\right)$, and minus the energy expended during the bearers' return trip $\left(\mathrm{ET}_{z y}\right)$ :

$$
\mathrm{EP}_{z}=\mathrm{EA}_{y}-\mathrm{ET}_{y z}-\mathrm{ET}_{z y}
$$

And if EA is equal to the energy acquired per bearer load (ea) multiplied by the number of bearers $(b)$, then

$$
\mathrm{EA}_{y}=e a_{y} \times b
$$

And if ET is equal to the energy expenditure per bearer per day $(e t)$, multiplied by the number of bearers $(b)$, multiplied by the number of days $(t)$ to transport the energy, and if $t_{y z}$ and $t_{z y}$ respectively represent the number of days taken to travel from $y$ to $z$ and $z$ to $y$, then

$$
\mathrm{ET}_{y z}=e t_{y z} \times b \times t_{y z} \text { and } \mathrm{ET}_{z y}=e t_{z y} \times b \times t_{z y}
$$

Given the above, then

$$
\mathrm{EP}_{z}=\left(e a_{y} \times b\right)-\left(e t_{y z} \times b \times t_{y z}\right)-\left(e t_{z y} \times b \times t_{z y}\right)
$$

Moreover, if the possibility that the bearers can acquire energy $(e a)$ at intermediate locations $x(x=1,2, \ldots, n)$ en route is allowed for $\left(e a_{x}\right)$, then the final model is

$$
\begin{aligned}
\mathrm{EP}_{z}= & \left(e a_{y} \times b\right)-\left(e t_{y z} \times b \times t_{y z}\right)-\left(e t_{z y} \times b \times t_{z y}\right) \\
& +\sum_{x=1}^{n} e a_{x} \times b
\end{aligned}
$$

\section{MAIZE TRANSPORT FROM ZEMPOALA TO TENOCHTITLAN}

The transport of maize from central Veracruz to the Basin of Mexico during the sixteenth-century famine provides an example of how the model works in practice and an opportunity to demonstrate the possibility of long-distance maize transport. In the interest of comparability, the calculations in this section are based on Drennan's assumptions for caloric content and energy expenditure. He suggests a standard $30-\mathrm{kg}$ load containing $108,300 \mathrm{Cal}$, a travel distance of $36 \mathrm{~km} /$ day, a consequent energy expenditure of 3,456 Cal/day, and a content of 3,610 Cal/kg for dry maize (Drennan 1984b:106; compare MSAS [1964], which claims ca. 3,500 Cal/kg of maize). As in Drennan's calculations, the following caloric expenditure figures come from Phillips (1954) and Clark and Haswell (1970). All maize quantities are in kilogram calories (Cal) and assume dry kernels removed from the cob.

Neither Durán (1867:Chapter XXX) nor Torquemada (1969: Book II, Chapter XLVII) indicates how much maize the Totonac brought up from the coast other than to suggest that the quantity was significant enough to ameliorate the famine. The exact amount is not at issue here, merely whether the Aztecs could profitably import a substantial amount of maize from the Totonacs. A caravan of 1,000 bearers carrying $30 \mathrm{~kg}$ each could have carried $30,000 \mathrm{~kg}$ of maize to Tenochtitlan. At 3,610 $\mathrm{Cal} / \mathrm{kg}$ of dry maize, this amount equals $1.083 \times 10^{8} \mathrm{Cal}$ and would have been enough to sustain some 2,200 people on an $80 \%$ maize diet for one month (cf. Sanders 1976b:109). At $36 \mathrm{~km} /$ day, the caravan would have taken 11 days to cover the $396-\mathrm{km}$ route and, assuming the bearers overnighted at the same encampments, another 11 days to return. During this period the Aztecs were importing the maize as tribute, and therefore the Totonac bearers would have returned unladen.

A liberal estimate of Tenochtitlan's population is some 300,000 inhabitants (Sanders 1976b:Table 4.9). Therefore, 1,000 bearers making the round trip once per month could have only sustained some $.75 \%$ of the population. To significantly ameliorate the famine would have required some 50 such caravans of 1,000 bearers every month for the duration of the famine, thus sustaining some $37 \%$ of Tenochtitlan's population. The population of Zempoala was probably on the order of 80,000 120,000 (Kelly and Palerm 1952:Table 14). And Cortés (1988:32) reported that the province of Zempoala could raise 50,000 war- 
riors. Therefore, such a scenario seems sufficiently plausible to provide the basis for the following demonstration of the model.

Using the model (Equation 5 above) to solve for the energy profit at location $z\left(\mathrm{EP}_{z}\right)$ and letting

$$
\begin{aligned}
z & =\text { Tenochtitlan } \\
y & =\text { Zempoala } \\
e a_{x} & =0 \mathrm{Cal} \\
e a_{y} & =108,300 \mathrm{Cal} / \text { bearer (30-kg load of maize) } \\
b & =1,000 \text { bearers } \\
e t_{y z} & =3,456 \mathrm{Cal}=\text { bearer/day (laden; Table } 1) \\
e t_{z y} & =2,808 \mathrm{Cal} / \text { bearer/day (unladen; Table } 1) \\
t_{y z} & =11 \text { days } \\
t_{z y} & =11 \text { days }
\end{aligned}
$$

the $\mathrm{EP}_{z}$, at Tenochtitlan, is equal to $3.940 \times 10^{7} \mathrm{Cal}$, or only $36 \%$ of the $\mathrm{EA}_{y}$. Of the $1.083 \times 10^{8} \mathrm{Cal}$ acquired at Zempoala, $6.890 \times 10^{7} \mathrm{Cal}$ is lost to transport expenditures.

In order to have delivered their full loads, the bearers would have had to receive enough energy at 11 intermediate locations to offset the total transport expenditure: $6.890 \times 10^{7} \mathrm{Cal}$. Among the Aztecs, at least, the main meal of the day was at midday (Soustelle 1961:149-154). Assuming that each location $x$ contributed an equal amount of maize, that this was the daily total for each bearer, and that each location $x$ contributed maize at midday on the outward and the return trip, then $e a_{x}$ would be equal to $6,264 \mathrm{Cal}$. Tenochtitlan would have acquired, directly and indirectly, a total of $1.772 \times 10^{8} \mathrm{Cal}: 1.083 \times 10^{8}$ Cal from Zempoala and $6.890 \times 10^{7} \mathrm{Cal}$ from the intermediate locations. $\mathrm{EP}_{z}$ would have equaled $1.083 \times 10^{8} \mathrm{Cal}$.

Drennan claims that any energy acquired en route to offset transport expenditures $\left(e a_{x}\right)$ is nonetheless lost to the importer. However, the model can demonstrate that if Tenochtitlan attempted to extract the $6.890 \times 10^{7} \mathrm{Cal}$ directly from the intermediate locations and at the same time extract the $1.083 \times 10^{8}$ Cal directly from Zempoala, instead of using the former to feed bearers carrying the latter, the total $\mathrm{EP}_{z}$ would be less than $1.083 \times 10^{8} \mathrm{Cal}$. Treating each intermediate location as an ex-

Table 1. Table of daily caloric expenditures to walk unladen and to carry a $30-\mathrm{kg}$ load

\begin{tabular}{lccr}
\hline \hline & \multirow{2}{*}{$\begin{array}{c}\text { Hourly } \\
\text { Expenditure } \\
\text { Activity }\end{array}$} & \multicolumn{2}{c}{ Calories/Hours } \\
\cline { 3 - 4 } & (Cal/Hour) & $30-\mathrm{kg}$ Load & Unladen \\
\hline Carrying $30 \mathrm{~kg}$ & 265 & $2,120 / 8$ & \\
Walking unladen & 184 & & $1,472 / 8$ \\
Sitting & 78 & $468 / 6$ & $468 / 6$ \\
Sleeping & 62.5 & $500 / 8$ & $500 / 8$ \\
Miscellaneous activity & 184 & $368 / 2$ & $368 / 2$ \\
Daily totals & & $3,456 / 24$ & $2,808 / 24$ \\
\hline \hline
\end{tabular}

Note: Daily caloric expenditures after Drennan (1984b:Table 1); data from Clark and Haswell (1970:13) and Phillips (1954:Table 2). porter ( $y$ ), Figure 2 graphs the output of the model, that is, the energy profit $\left(\mathrm{EP}_{z}\right)$ at Tenochtitlan for each intermediate location given that

$$
\begin{aligned}
z= & \text { Tenochtitlan } \\
y= & \text { an exporting location } .5 \text { days from } z, 1.5 \text { days from } \\
& z, \ldots, 10.5 \text { days from } z \\
e a_{x}= & 0 \mathrm{Cal} \\
E A_{y}= & 6.264 \times 10^{6} \mathrm{Cal}(6,264 \mathrm{Cal} \times 1,000 \text { bearers }) \\
e a_{y}= & 108,300 \mathrm{Cal} / \text { bearer }(30-\mathrm{kg} \text { load of maize) } \\
b= & 58 \text { bearers }\left(\mathrm{EA} y+e a_{y}\right) \\
e t_{y z}= & 3,456 \mathrm{Cal} / \text { bearer } / \text { day (laden; Table } 1) \\
e t_{z y}= & 2,808 \mathrm{Cal} / \text { bearer } / \text { day (unladen; Table } 1) \\
t_{y z}= & .5 \text { days, } 1.5 \text { days, } \ldots, 10.5 \text { days } \\
t_{z y}= & .5 \text { days, } 1.5 \text { days, } \ldots, 10.5 \text { days }
\end{aligned}
$$

The sum of the $\mathrm{EP}_{z}$ s for all 11 intermediate locations equals $4.692 \times 10^{7} \mathrm{Cal}$.

Therefore, if Tenochtitlan would have directly extracted the energy from Zempoala and all the intermediate locations, the $\mathrm{EP}_{z}$ would only have equaled $8.632 \times 10^{7} \mathrm{Cal}: 4.692 \times 10^{7} \mathrm{Cal}$ from the intermediate locations and $3.940 \times 10^{7} \mathrm{Cal}$ from Zempoala. This amount is only $80 \%$ of the $1.083 \times 10^{8} \mathrm{Cal}$ gained if Tenochtitlan would have used the maize from the intermediate locations to feed the Totonac bearers from Zempoala. The difference of $20 \%$ is the expenditure made in transporting the maize from the intermediate locations to Tenochtitlan rather than using their energy in situ.

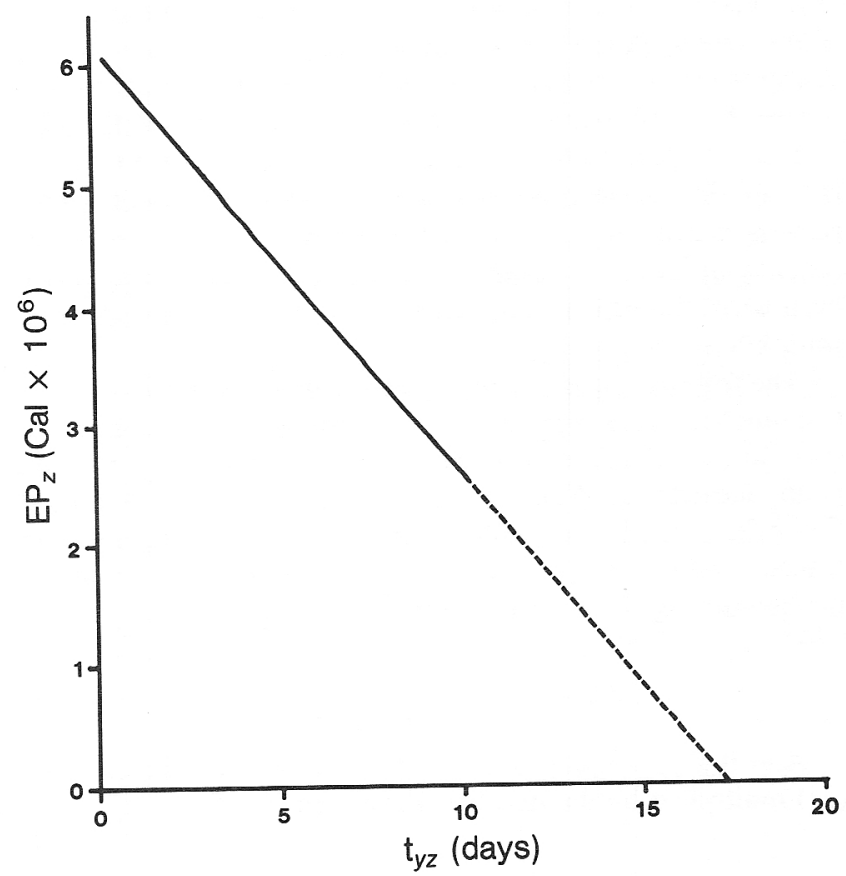

Figure 2. Graph of the energy profit at Tenochtitlan against travel time from Tenochtitlan. The dashed line extrapolates the function to $\mathrm{EP}_{z}=0$ Cal. $\mathrm{EA}_{\mathrm{y}}$ for each intermediate location $=6.264 \times 10^{6} \mathrm{Cal}$. 
Extrapolating Figure 2 demonstrates that attempting to directly extract maize from more than 17.5 days away, or $630 \mathrm{~km}$, would result in a negative $\mathrm{EP}_{z}$, a loss-even ignoring any profit-margin requirement. However, utilizing maize from intermediate locations more than $630 \mathrm{~km}$ away to feed bearers transporting maize from even further away would result in a positive $\mathrm{EP}_{z}$. The importer could have fully utilized a location's maize, at any distance, by utilizing it in situ, thus avoiding transportion expenditures. This strategy would hold true whether the maize fed a garrison, artisans, or bearers. This strategy would hold true whether one caravan of bearers transported the maize all the way or several caravans worked in relay, each within its own province. And this strategy would have been the only way to utilize maize from distant locations.

\section{DISCUSSION}

The model demonstrates that as long as the importer controlled food energy at locations at regular intervals of approximately $36 \mathrm{~km}$ intermediate to itself and the exporter, long-distance staple transport was both possible and profitable. Control could have been through military force, economic domination, kin reciprocity, or other means. Certainly this control might also have entailed costs (Drennan 1984a:106), such as maintaining garrisons and tribute collectors. But such costs, and also those of the actual maize production, would have been borne locally and would not have incurred transport costs (Zeitlin 1991:375377). Theoretically, therefore, no maximum distance existed beyond which staple transport became energetically unprofitable. Clearly however, the model only demonstrates that longdistance maize transport was feasible, not that it actually took place on a regular basis.

On the one hand, perhaps long-distance staple transport was the exception rather than the rule, being limited to times of famine such as Durán (1867:Chapter XXX) and Torquemada (1969:Book II, Chapter XLVII) record. In support of that view, the Aztec tribute lists, now known through the Codex Mendoza and the Matricula de tributos, indicate that 19 of the 20 provinces that paid maize to Tenochtitlan fell within Drennan's maximum distance of $275 \mathrm{~km}$ (Figure 3). Therefore, and despite possible overpopulation in the Basin of Mexico during the Late Postclassic (Williams 1989), these ethnohistoric data suggest that

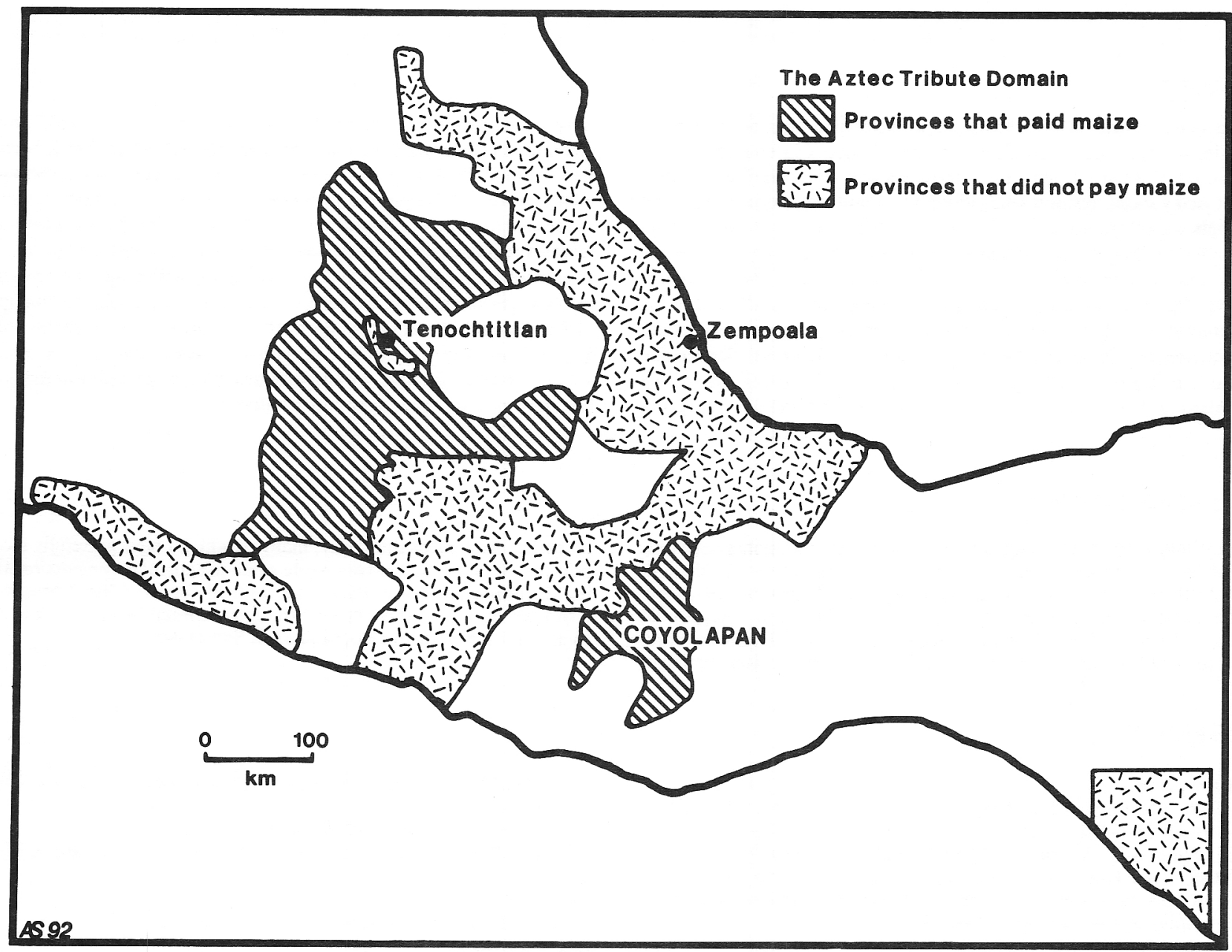

Figure 3. Provinces of the Aztec domain that paid maize tribute to Tenochtitlan according to the Matricula de tributos. Only the province of Coyolapan is named (after Barlow 1949). 
long-distance staple transport was not common. Drennan dismisses the other province, Coyolapan, as an anomaly (Drennan 1984b:107). However, a more careful reading of the Matricula reveals that all of the the Coyolapan maize that came from the town of Teotzacualco went to feed a local Aztec garrison rather than going to Tenochtitlan, thus further supporting the empirical case against long-distance staple transport (Barlow 1949: 125). The rest of the Coyolapan maize came from the town of Quauxilotitlan and might also have gone to the garrison at Teotzacualco, only some $20 \mathrm{~km}$ away.

On the other hand, Mesoamericanists as yet understand so little about the "rules" that the exceptions remain completely enigmatic. Ethnohistorical data, such as the Codex Mendoza and the Matricula de tributos, only reveal the situation during the last century before European contact, and then only equivocally and incompletely. The nature of interregional exchange during the previous millennia is still far from clear and should be the subject of investigation rather than preconception. Archaeological data bearing on interregional exchange remain few (see Smith [1990] for a critical review and analysis). Given that interregional exchange networks might have originated during the Early Preclassic period to ameliorate seasonal or annual maize harvest fluctuations (Flannery and Schoenwetter 1970:
148-150), the search for new data and methods should consider staples as well as durable goods.

\section{CONCLUSIONS}

While this discussion has focused on western Mesoamerica, the model has a wider significance and application. Researchers in other regions that lacked draft animals and water transportation might also profit by considering this model's implications.

To reiterate them, this quantitative model does not prove that Mesoamerican peoples transported maize or any other staple long distances. Drennan's hypothesis regarding the role of staple vs. luxury goods in the process of Preclassic- and Classic-period social stratification (Drennan 1984a) remains valid - although untested. However, the model does prove that conclusions regarding the impossibility of long-distance staple transport are in error. And it does demonstrate the error of discounting longdistance staple transport on logical and energetics grounds alone. Such transport was energetically possible; whether it actually took place remains an empirical question that must consider culture as well as energy (Zeitlin 1991). Only further data will eventually illuminate the nature of Mesoamerican interregional exchange and its role in social and ecological processes.

\section{RESUMEN}

La conceptualización del transporte pre-hispánico de productos principales continúa sin desarrollarse. A pesar de que el intercambio interregional y el tributo tienen un rol central en muchos modelos del proceso ecológico y social, pocos investigadores han examinado sistematicamente la logística del transporte. Los aztecas y sus predecesores no dispusieron de vias fluviales adecuadas para el transporte, ni de animales de carga, por lo que debieron emplear cargadores para el transporte terrestre. En consecuencia, la sabiduría convencional mantiene que los productos principales se transportaron a "corta distancia"; solamente productos de lujo, como el cacao y la jadeita tuvieron un alcance que requirió el transporte a "larga distancia." Un modelo cuantitativo revela la falsedad de ese argumento y establece la posibilidad del transporte terrestre de productos principales a larga distancia, utilizando como ejemplo el transporte del tributo de maíz entre Zempoala y Tenochtitlan. El modelo demuestra que el transporte de productos principales a larga distancia fue posible y productivo, siempre y cuando el importador controlara el suplemento de comida en localidades situadas a intervalos regulares de aproximadamente $36 \mathrm{~km}$ entre él y el exportador. El control pudo haberse dado a través de dominación militar o económica. Teoreticamente, por lo tanto, no existió una distancia máxima mas allá de la cual el transporte de productos principales se tornó energeticamente improductivo. Sin embargo, está claro que el model solamente demuestra que el transporte de maíz a larga distancia fue posible, pero no que tuvo lugar con regularidad.

\section{ACKNOWLEDGMENTS}

The stimulus for developing and articulating my arguments regarding pre-Hispanic staple transport came from "discussions" with William E. Doolittle while in Chihuahua and Sonora during August of 1991. Doolittle, Dean P. Lambert, Karl W. Butzer, B. L. Turner II, Gregory W. Knapp, J. Dennis Lord, William R. Fowler, Robert D. Drennan, Barry L. Isaac, and several anonymous reviewers have made critical comments

\section{REFERENCES}

Barlow, R.H.

1949 The Extent of the Empire of the Culhua Mexica. Ibero-Americana 28:1-141.

Bell, Thomas L., Richard L. Church, and Larry Gorenflo

1988 Late Horizon Regional Efficiency in the Northeastern Basin of Mexico: A Location-Allocation Perspective. Journal of Anthropological Archaeology 7:163-202.

Blacker, I.R.

1963 Prescott's Histories. Viking Press, New York.

Chapman, Anne C.

1957 Port of Trade Enclaves in Aztec and Maya Civilizations. In Trade and Market in the Early Empires, edited by K. Polanyi, C.M. on earlier versions of this paper, many of which I have gratefully incorporated. William G. Gartner made some insightful comments regarding the importance of cultural and political context when I presented a shorter version of this paper at the 1992 Annual Meeting of the Association of American Geographers in San Diego.

Arensberg, and Harry W. Pearson, pp. 114-53. Free Press, Glencoe, IL.

Clark, Colin, and Margaret Haswell

1970 The Economics of Subsistence Agriculture. MacMillan, London.

Cortés, Hernán

1988 Cartas de relación. Porrúa, Mexico.

Dalton, George

1975 Karl Polanyi's Analysis of Long-Distance Trade and His Wider Paradigm. In Ancient Civilization and Trade, edited by J.A. Sabloff and C.C. Lamberg-Karlovsky, pp. 63-132. University of New Mexico Press, Albuquerque. 
Davies, Nigel

1973 The Aztecs: A History. G.P. Putnam's Sons, New York.

Denevan, William M.

1976 Estimating the Unknown. In The Native Population of the Americas, edited by William M. Denevan, pp. 1-12. University of Wisconsin Press, Madison.

1982 Hydraulic Agriculture in the American Tropics: Forms, Measures, and Recent Research. In Maya Subsistence: Studies in Memory of Dennis E. Puleston, edited by Kent V. Flannery, pp. 181-203. Academic Press, New York.

Denevan, William M., and B.L. Turner II

1985 Calculating Population and Agricultural Intensity Levels from Field Remains: A Comment on Coe's Review of "Maya Subsistence." American Antiquity 50:166-169.

Doolittle, William E.

1990 Canal Irrigation in Prehistoric Mexico: The Sequence of Technological Change. University of Texas Press, Austin.

Drennan, Robert D.

1984a Long-Distance Movement of Goods in the Mesoamerican Formative and Classic. American Antiquity 49:27-43.

1984b Long-Distance Transport Costs in Pre-Hispanic Mesoamerica. American Anthropologist 86:105-112.

1985 Porters, Pots, and Profit: The Economics of Long-Distance Exchange in Mesoamerica. American Anthropologist 87:891-93.

Durán, Diego

1867 Historia de las indias de Nueva España y islas de tierra firma. 2 vols. J.M. Andrade y F. Escalante, Mexico.

Flannery, Kent V., and James Schoenwetter

1970 Climate and Man in Formative Oaxaca. Archaeology 23: 144-152.

Hassig, Ross

1981 The Famine of One Rabbit: Ecological Causes and Social Consequences of a Pre-Columbian Calamity. Journal of Anthropological Research 37:172-182.

1985 Trade, Tribute, and Transportation in the Sixteenth Century Political Economy of the Valley of Mexico. University of Oklahoma Press, Norman.

1986 One Hundred Years of Servitude: Tlamemes in Early New Spain. In Ethnohistory, edited by Ronald Spores, pp. 134-152. Supplement to the Handbook of Middle American Indians, vol. 4. University of Texas Press, Austin.

Hirth, Kenneth G.

1991 Roads, Thoroughfares, and Avenues of Power at Xochicalco, Mexico. In Ancient Road Networks and Settlement Hierarchies in the New World, edited by C.D. Trombold, pp. 211-221. Cambridge University Press, Cambridge.

Kelly, Isabel, and Angel Palerm

1952 The Tajin Totonac: Part 1. History, Subsistence, Shelter and Technology. Institute of Social Anthropology, Smithsonian Institution, Washington, DC.

Jochim, Michael A.

1981 Strategies for Survival: Cultural Behavior in an Ecological Context. Academic Press, New York.

Logan, Michael H., and William T. Sanders

1976 The Model. In The Valley of Mexico: Studies in Pre-Hispanic Ecology and Society, edited by E.R. Wolf, pp. 31-58. University of New Mexico Press, Albuquerque.

MSAS (Ministerio de Sanidad y Asistencia Social)

1964 Tabla de composición de alimentos para uso práctico. Instituto Nacional de Nutrición, Caracas.

Phillips, P.G.

1954 The Metabolic Cost of Common West African Agricultural Activities. Journal of Tropical Medicine and Hygiene 57:12-20.

Polanyi, Karl, Conrad M. Arensberg, and Harry W. Pearson

1957 Trade and Market in the Early Empires. Free Press, New York.

Price, Barbara J.

1978 Commerce and Cultural Process in Mesoamerica. In Mesoamerican Communication Routes and Cultural Contacts, edited by
T.A. Lee, Jr., and C. Navarrete, pp. 231-245. New World Archaeological Foundation, Provo, UT.

Rees, Peter W.

1975 Origins of Colonial Transport in Mexico. Geographical Review $65: 323-334$

Renfrew, Colin

1975 Trade as Action at a Distance: Questions of Integration and Communication. In Ancient Civilization and Trade, edited by J.A. Sabloff and C.C. Lamberg-Karlovsky, pp. 3-59. University of New Mexico Press, Albuquerque.

Reyman, Jonathan E., and Robert Dirks

1985 Comments on Drennan's "Long Distance Transport Costs in Pre-Hispanic Mesoamerica." American Anthropologist 87:889-891. Sanders, William T.

1976a The Agricultural History of the Basin of Mexico. In The Valley of Mexico: Studies in Pre-Hispanic Ecology and Society, edited by E.R. Wolf, pp. 101-159. University of New Mexico Press, Albuquerque.

1976b The Population of the Central Mexican Symbiotic Region, the Basin of Mexico, and the Teotihuacan Valley in the Sixteenth Century. In The Native Population of the Americas, edited by William M. Denevan, pp. 85-150. University of Wisconsin Press, Madison.

Sanders, William T., Jeffrey R. Parsons, and Robert S. Santley

1979 The Basin of Mexico: Ecological Processes in the Evolution of a Civilization. Academic Press, New York.

Sanders, William T., and Robert S. Santley

1983 A Tale of Three Cities: Energetics and Urbanization in PreHispanic Central Mexico. In Prehistoric Settlement Patterns: Essays in Honor of Gordon R. Willey, edited by E.Z. Vogt and R.M. Leventhal, pp. 243-291. University of New Mexico Press and Peabody Museum of Archaeology and Ethnology, Cambridge.

Siemens, Alfred $\mathrm{H}$.

1989 Tierra configurada. Consejo Nacional para la Cultura y los Artes, Mexico.

Sluyter, Andrew

1990 Vestiges of Upland Fields in Central Veracruz: A New Perspective on its Precolumbian Human Ecology. Master's thesis, Department of Geography, University of British Columbia. National Library of Canada Microfilms, Ottawa.

Sluyter, Andrew, and Alfred H. Siemens

1992 Vestiges of Prehispanic, Sloping-Field Terraces on the Piedmont of Central Veracruz, Mexico. Latin American Antiquity $3: 148-160$.

Smith, Michael E.

1990 Long-Distance Trade Under the Aztec Empire. Ancient Mesoamerica 1:153-169.

Soustelle, Jacques

1961 Daily Life of the Aztecs on the Eve of the Spanish Conquest. Stanford University Press, Stanford.

Torquemada, Juan de

1969 Monarquía indiana. 3 vols. Editorial Porrua, Mexico.

von Thünen, Johann Heinrich

1966 Isolated State. Pergamon, Oxford.

West, Robert C., and John P. Augelli

1966 Middle America: Its Lands and Peoples. Prentice-Hall, Englewood Cliffs, NJ.

Williams, Barbara J.

1989 Contact Period Rural Overpopulation in the Basin of Mexico: Carrying-Capacity Models Tested with Documentary Data. American Antiquity 54:715-732.

Zeitlin, Robert N.

1991 The Energetics of Trade and Market in the Early Empires of Mesoamerica. Research in Economic Anthropology 13:373-386.

Zipf, George K.

1949 Human Behavior and the Principle of Least Effort. AddisonWesley, Cambridge, MA. 